\title{
Effect of Lyophilized Bovine Colostrum on Growth and Survival of Newborn Piglets From Local Breed, in Benin Republic
}

\author{
Aristide Mahoutin Agbokounou \\ Beninese Center for Scientific Research and Innovation (CBRSI), \\ Republic of Benin \\ Gbênagnon Serge Ahounou \\ Issaka Youssao Abdou Karim
}

Department of Animal Production and Health, Polytechnic School of Abomey-Calavi, Cotonou, University of Abomey-Calavi, Republic of Benin

\section{Guy Apollinaire Mensah}

National Institute for Scientific Research, Research Center of Agonkanmey (CRA / INRAB), Abomey-Calavi, Republic of Benin

\section{Bénoît Koutinhouin}

Department of Animal Production and Health, Polytechnic School of Abomey-Calavi, Cotonou, University of Abomey-Calavi, Republic of Benin Jean-Luc Hornick

Tropical Veterinary Institute, Department of Animal Production, Faculty of Medicine Veterinary, University of Liège 20 Bd de Colonster, Liège, Belgium

Doi: 10.19044/esj.2018.v14n21p302 URL:http://dx.doi.org/10.19044/esj.2018.v14n21p302

\begin{abstract}
In Benin, the effect of supplementation of newborn piglets from local breed with lyophilized bovine colostrum was evaluated over a 49-d trail on the survival, the growth performances and the absorption of bovine and porcine immunoglobulin G (IgGs). Three groups of 24 piglets, stemming from five sows (Parity 2) belonging to a unique traditional farm, were respectively fed for the first $7 \mathrm{~d}$ of life with only sow colostrum (SC group $\mathrm{n}$ $=9$ ), shea butter in addition to suckling (SCB group; $n=7$ ) and a mixture of lyophilized bovine colostrum and shea butter in addition to suckling (BCB group; $n=8$ ). Risk of diarrhea was not affected by the treatments, but BCB treatment tended to reduce it $(P=0.09)$. Diarrheal and healthy piglets had similar average levels of serum porcine $\mathrm{IgG}$ at $10 \mathrm{~d}(13.9 \pm 1.6 \mathrm{mg} / \mathrm{ml}$ vs 14.7 $\pm 1.4 \mathrm{mg} / \mathrm{ml}, \mathrm{P}>0.05)$. No bovine $\mathrm{IgG}$ was detected in the piglets serum at $10 \mathrm{~d}$ of age. Serum porcine IgG at $10 \mathrm{~d}$ was not affected by the treatments (P $>0.05)$. However, bovine colostrum improved serum IgG at $49 \mathrm{~d}(\mathrm{P}<0.05)$.
\end{abstract}


No significant difference $(\mathrm{P}>0.05)$ was observed between the three groups for body weight and Average Daily Gain (ADG). By contrast, Relative Average Daily Gain (RADG) was affected by the treatments $(\mathrm{P}<0.05)$. The lyophilized bovine colostrum improved numerically ADG when compared to the piglets fed only with the colostrum from the sow and those fed also shea butter (41g vs 35 and $36 \mathrm{~g} / \mathrm{d}$ for the first and second groups respectively). A higher RADG was obtained with the piglets from the BCB group (31 \pm 1.6 g/d.kg vs $25.3 \pm 1.6 \mathrm{~g} / \mathrm{d} . \mathrm{kg}$ and $24.5 \pm 1.9 \mathrm{~g} / \mathrm{d} . \mathrm{kg}$ for the SC and SCB groups respectively). Lyophilized bovine colostrum improved RADG, active immunity at weaning and tended to reduce prevalence of diarrhea in newborn piglets.

Keywords: Lyophilized bovine colostrum, sow, local breed piglet, Benin, immunoglobulin G

\section{Introduction}

In southern Benin, small livestock occupy 85 to $95 \%$ of households with a high concentration of pig farming (Nonfon, 2005). This pig breeding plays an important role in the socio-economic life of the beninese population. At the social level, pork is used in some ancestral funerary rites of the majority of ethnic groups in the south of the country and in national celebration ceremonies. At the economic level, the breeding of pork provides income to several socio-professional groups such as artisans, agro-pastoralists, small traders and other beneficiaries such as students, teachers, military, and other officials (Youssao et al., 2008). Among the pig breeds raised in Benin, the local breed is prominently. This local pig breed is the one found in several west african countries. It is raised mainly in traditional farms and could ensure sustainable incomes for small farmers. This breed provides significant income and thereby contributes to fighting poverty (Chimonyo et al., 2010; Carter et al., 2013). As local breeds belonging to other animal species, the local pigs breed are a valuable genetic resource that must be preserved and promoted in traditional livestock systems as it contributes to the prosperity of subsistence agricultural systems in Africa (Amills et al., 2013). In Benin where the pig population is rebuilding following the outbreak of african swine fever in 1997 , the local breed is unfortunately endangered due to uncontrolled crossbreeding observed in recent years to meet increasing demand for pork meat. In this context, three challenges are essential: sustain income for rural communities, rebuild the pig population and meet the requirements of the Convention on Biological Diversity of Rio for preservation of indigenous breeds.

Improving the productivity of local sow breed is one of the options to rebuilding the pig population and preserving the indigenous breed. 
Improving productivity of sow, resulting in mortality reduction, implies efficient management of pre and post-weaning which are two critical periods in piglet life. The only feeds for piglet are colostrum in the first hours of life and milk afterwards. Adequate colostrum intake promotes significant reduction in mortality, adequate passive immunity and ideal weight gain (Quesnel, Farmer \& Devillers, 2012; Ferrari et al., 2014). Unfortunately, a third of sows seem not to produce enough colostrum to meet piglet requirements (Quesnel et al., 2012), explaining most of the deaths occurring in the 1st days of life. Low colostrum production by sows could be compensated by heterologous colostrum that could be used as a source of immunoglobulin $\mathrm{G}$ ( $\mathrm{IgG}$ ) in newborn piglets (Stirling et al., 2005). Bovine colostrum seems indicated in this case. Distribution of bovine colostrum to piglet at birth also could increase supply of immunoglobulins, bioactive peptides and growth factors (Boudry, 2009), although the specificity of these immunoglobulins to pig pathogens is a research question. Additionally, Agbokounou et al. (2017a) showed that the intake of thawed bovine colostrum during the first 48 hours of life improved the survival rate and the growth performance in local pig breed in Benin, probably owing to thermally labile components. In this context, the use of bovine colostrum by farmers could be an alternative to improve growth performance and reduce mortality rate of piglets before weaning. It could help support piglets in difficult farming conditions. However, the use of fresh bovine colostrum in traditional farms remains a major concern because of the poor storage conditions for this product. The use of lyophilized colostrum could be a solution. This study aims to evaluate the effect on local piglets breed reared with their mother of supplementation with lyophilized bovine colostrum when considering survival, growth performance and absorption of bovine and porcine IgGs.

\section{Materials and methods}

This study has been approved by the Committee for Animal Experiments of the Department of Animal Production and Health of Polytechnic School of University of Abomey-Calavi of Benin. The methods used in this protocol involving animals were in accordance with the ethical standards of this institution. So, all applicable guidelines for the care and use of animals of this institution were followed during this study.

\section{Experimental site}

The study was performed from November 2015 to June 2016 in a traditional livestock located in 5th district of Porto-Novo, Benin. The climate is sub-equatorial with four seasons: two rainy (long rain season from April to July, short rain season from September to November) and two dry (long dry season from December to March, short dry season in July-August) with a 
maximum relative humidity observed in June and July. The average prevailing daytime temperature was $27.5^{\circ} \mathrm{C}$ and average annual rainfall was 1300 mm (Osseni et al., 2014).

\section{Housing, feeding and management}

Animal health and feeding management was traditional. The habitat is made of brick walls with separated individual box for pregnant sows. The roof is covered with sheet metal and the floor is made of concrete. The sows were fed during all the phases of reproduction with a simple diet often consisting of malt brewery and sometimes of maize bran or kitchen waste, according to availability of the products. The animals had free access to water and received no veterinary care. They were mated with the same boar.

The lyophilized bovine colostrum used was provided by European Colostrum Industry (ECI®, Belgium) which guarantees 70g/l antibodies. Shea butter, a vegetal fat derived from the traditional processing of the shea nuts was provided by local market. It was used, mixed with colostrum powder, to facilitate the distribution of colostrum to piglets.

\section{Animals and experimental design}

Twenty four (24) piglets born from five (05) sows (parity 2) were used in this study. At farrowing, the piglets were separated from their mother and weighed to the constitution of the experimental groups. The groups were matched on the basis of sex and birth weight (BW) of the piglets so that the average weights were similar and not significantly different between groups. After group allocation, the piglets were returned to the mother. Under each sow, each group was randomly allocated to one of the three treatments. One group was fed only with sow colostrum through suckling (SC group $n=9$ ). The other two groups were fed during the first $7 \mathrm{~d}$ of piglet's life in addition to suckling, $6 \mathrm{~g}$ shea butter either alone (SCB group; $\mathrm{n}=7$ ) or mixed with 2 g lyophilized bovine colostrum (BCB group; $n=8)$ divided in three doses every $3 \mathrm{~h}$. All piglets were weighed weekly until $49 \mathrm{~d}$ of age. Their survival was also followed under the sow from birth to $49 \mathrm{~d}$.

\section{Blood samples collection and analyses}

Blood samplings $(5 \mathrm{ml})$ were collected on each piglet at 10 and $49 \mathrm{~d}$ of life by anterior vena cava puncture using a $21 \mathrm{G}$ needle and vacuum tube (vacutainer). Blood was centrifuged and serum stored in a continuous chain of cold until analyses.

These analyses were performed at Laboratory IODOLAB (MarcyL'Etoile, France) for porcine and bovine IgG measurements by Radial Immunodiffusion (RID) technique. 


\section{Statistical analysis}

Data were analyzed by the Statistical Analysis System (SAS, 1999) software. Weekly body weight, Average Daily Gain (ADG) and Relative ADG (RADG, i.e., ratio of ADG to mean weight of the week) were analyzed using a mixed model including the effects of treatment, sow, time, and the interactions sow $*$ treatment, treatment $*$ time. The model allowed the inclusion of a type 1 autocorrelative covariance structure between repeated data measured on same animal. The Effects of treatment on the blood-serum concentrations of porcine IgG were evaluated by analyses of variance (ANOVA) using a General Linear Model. The Student's t-test adjusted for multiple comparisons was used to compare averages. Moreover, relationships between piglet diarrhea as dependent variable and treatment were evaluated by a binary logistic regression model including the effect of sow and the interaction sow $*$ treatment.

\section{Results}

\section{Piglets health and survival}

Diarrhea was the visible symptom observed in this study. During the trial, $13 \%, 44 \%$ and $57 \%$ of the piglets from the BCB, SC and SCB groups suffered from diarrhea respectively. This one was observed mainly from the $3^{\text {rd }}$ to $4^{\text {th }}$ week in three sows. Moreover, among these $57 \%$ piglets from SCB group, half showed this symptom between 7 and $14 \mathrm{~d}$. The risk of diarrhea was not affected by the treatments $(\mathrm{P}>0.05)$. Compared to SCB as "neutral", $\mathrm{SC}$ treatment decreased the risk of diarrhea by 1.7 times without being significant $(\mathrm{P}>0.05)$, whereas $\mathrm{BCB}$ decreased it by 9 times with a tendency to be significant $(\mathrm{P}=0.0947)$. Two (2) piglets from SCB group that had suffered from diarrhea, died between the $3^{\text {rd }}$ to the $4^{\text {th }}$ week of life. By contrast, no mortality was observed in the SC and BCB groups. The averages serum $\operatorname{IgG}$ concentrations at $10 \mathrm{~d}$ of diarrheic and healthy piglets (13.9 and $14.7 \mathrm{mg} / \mathrm{ml}$ respectively) were similar $(\mathrm{P}>0.05)$.

\section{Growth performance of the piglets}

Initial body weight (BW) was similar between groups ( $\mathrm{P}>0.05)$. Growth performances are shown in table 1 . The evolution of body weight, ADG and RADG in the different groups are depicted in Figures 1, 2 and 3 respectively.

The body weight was not affected by the treatments $(\mathrm{P}>0.05)$. Thus, from birth to $49 \mathrm{~d}$ of life, the average body weights of the three groups were not significantly different. As a mean, the piglets of the BCB and SCB groups had body weights ( $1659 \pm 154 \mathrm{~g}$ and $1627 \pm 165 \mathrm{~g}$ respectively) slightly and numerically greater than that of the SC group $(1516 \pm 150 \mathrm{~g})$. Body weight increased steadily during the first three weeks of age in piglets of the groups 
BCB and SC. By contrast, piglets of the SCB group were characterized by a significant growth during the first week, a fall between 7 and $14 \mathrm{~d}$ followed by a rise between 14 and $21 \mathrm{~d}$. During the last four weeks of life, piglet growth in the three groups was low with a significant drop between 21 and $28 \mathrm{~d}$ (Figure 1). The average body weights obtained at $49 \mathrm{~d}$ of age were respectively $2213 \pm 158 \mathrm{~g}, 2372 \pm 181 \mathrm{~g}$ and $2493 \pm 162 \mathrm{~g}$ for SC, SCB and $\mathrm{BCB}$ groups. This trend was the same as that observed for weekly ADG, with a higher gain obtained between 7 and $14 \mathrm{~d}$ in piglets of the SC group and between 0 and $7 \mathrm{~d}$ with the SCB and BCB groups, a significant drop between 21 and $28 \mathrm{~d}$ in all groups (Figure 2). The ADG of the three groups were not significantly different $(\mathrm{P}>0.05)$ but with a higher numerical value for $\mathrm{BCB}$ group $(40.9 \pm 2.7 \mathrm{~g}$ vs $34.6 \pm 2.6$ and $35.5 \pm 3.1 \mathrm{~g}$ for $\mathrm{SC}$ and SCB groups respectively). According to the RADG, it decreased steadily from 7 to $28 \mathrm{~d}$ of age in the piglets of the SC and BCB groups. As regards the piglets of the SCB group, RADG showed a continuous drop from 7 to $14 \mathrm{~d}$, a ceiling from 14 to $21 \mathrm{~d}$ and a fall thereafter (Figure 3 ). It was affected by the treatment (P $<0.05)$, sow and time $(\mathrm{p}<0.001)$. The higher RADG was obtained with piglets of the $\mathrm{BCB}$ group $(31 \pm 1.6 \mathrm{~g} / \mathrm{d} . \mathrm{kg}$ vs $25.3 \pm 1.6 \mathrm{~g} / \mathrm{d} . \mathrm{kg}$ and $24.5 \pm 1.9$ $\mathrm{g} / \mathrm{d} . \mathrm{kg}$ for the SC and SCB groups respectively).

None of these parameters was affected by the treatment*time and sow*treatment interactions $(\mathrm{P}>0.05)$.

Table 1: Growth performance of piglets raised by sow and receiving or not during the first week of life Shea butter mixed or not with lyophilized bovine colostrum

\begin{tabular}{|c|c|c|c|c|c|c|c|c|c|}
\hline \multirow{2}{*}{ Parameters } & \multicolumn{2}{|c|}{$\mathrm{SC}(\mathrm{n}=9)$} & \multicolumn{2}{|c|}{$\mathrm{SCB}(\mathrm{n}=7)$} & \multicolumn{2}{|c|}{$\mathrm{BCB}(\mathrm{n}=8)$} & \multirow{2}{*}{ Ttmt } & \multirow{2}{*}{ Sow } & \multirow{2}{*}{ Time } \\
\hline & Mean & SE & Mean & SE & Mean & SE & & & \\
\hline Birth weight (g) & 491.55 & 158.06 & 547.72 & 173.58 & 469.39 & 162.33 & & & \\
\hline $\begin{array}{l}\text { Live weight from birth } \\
\text { to } 49 \mathrm{~d}(\mathrm{~g})\end{array}$ & 1516.45 & 150.33 & 1626.72 & 165.40 & 1658.75 & 154.13 & NS & $* * *$ & $* * *$ \\
\hline Weight at d $49(\mathrm{~g})$ & 2213.03 & 158.07 & 2372.23 & 181.45 & 2492.77 & 162.34 & NS & $* * *$ & $* * *$ \\
\hline Weekly ADG (g/d) & 34.58 & 2.60 & 35.50 & 3.14 & 40.86 & 2.66 & NS & $* * *$ & $* * *$ \\
\hline $\begin{array}{l}\text { Weekly RADG } \\
\text { (g/d.kg) }\end{array}$ & $25.31 b$ & 1.55 & $24.47 b$ & 1.89 & $31.00 \mathrm{a}$ & 1.59 & $*$ & $* * *$ & $* * *$ \\
\hline
\end{tabular}

SC: Sow colostrum; SCB: Sow colostrum butter; BCB: Bovine colostrum butter; Ttmt:

Treatment; SE: Standard Error; NS: No significant; *: P < 0.05; ***: P > 0.0005

Proportions of the same row followed by the same letters do not differ significantly at $5 \%$ 


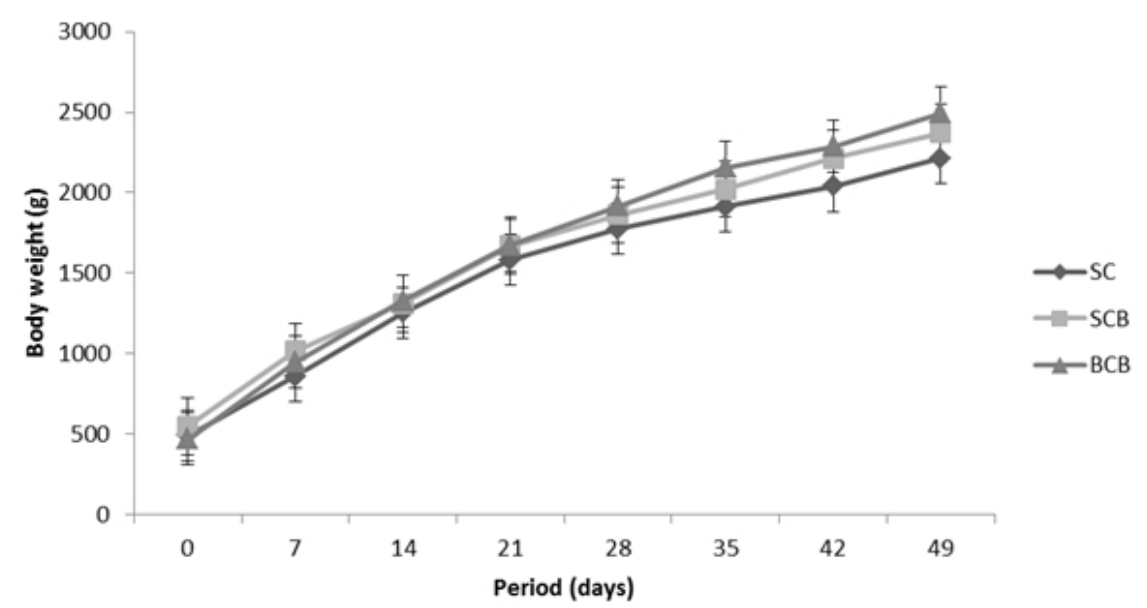

Fig 1: Evolution of body weight of piglets raised by sow and receiving or not during the first week of life Shea butter mixed or not with lyophilized bovine colostrum (bars indicates the SE value)

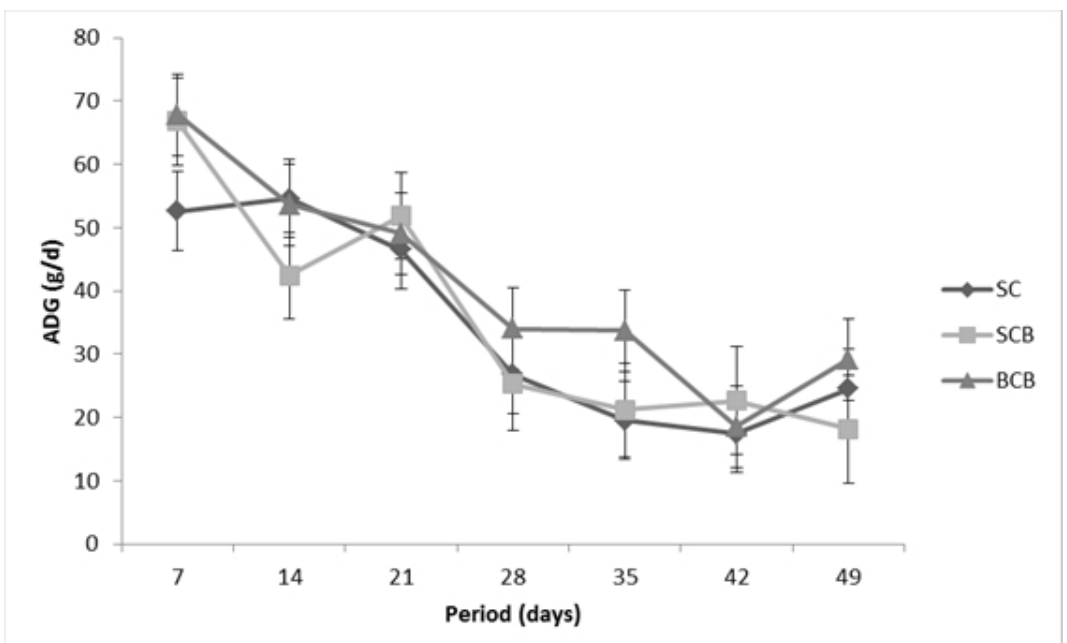

Fig 2 : Evolution of ADG of piglets raised by sow and receiving or not during the first week of life Shea butter mixed or not with lyophilized bovine colostrum (bars indicates the SE value) 


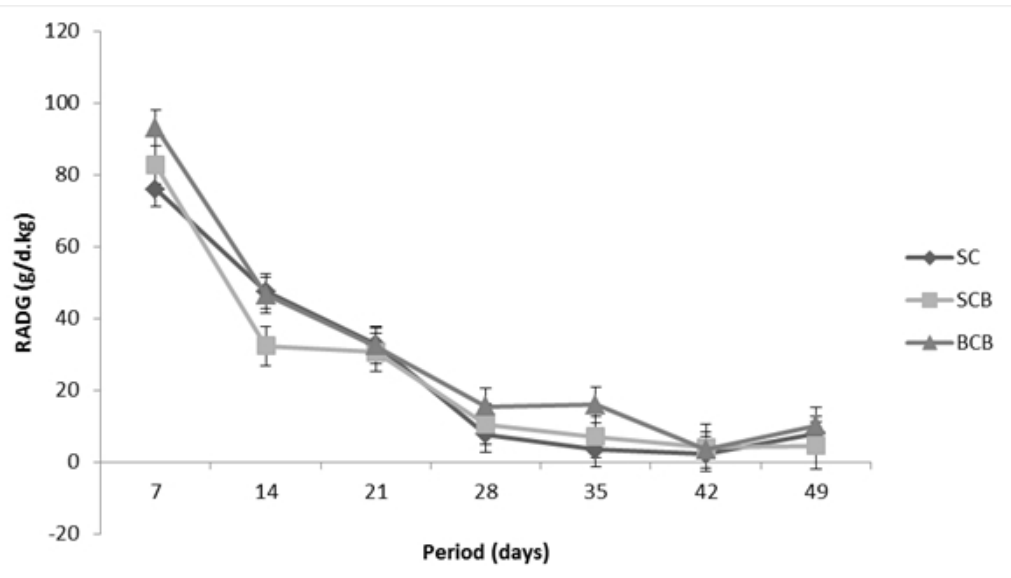

Fig 3 : Evolution of RADG of piglets raised by sow and receiving or not during the first week of life Shea butter mixed or not with lyophilized bovine colostrum (bars indicates the SE value)

\section{Immune transfer to piglets}

The analysis of serum samples showed that no bovine IgG was detected in the piglets serum of the three groups at 10 and $49 \mathrm{~d}$ of life. Porcine $\mathrm{IgG}$ was detected. In this case, serum $\mathrm{IgG}$ concentration at $10 \mathrm{~d}$ was not affected by treatment $(\mathrm{P}>0.05)$. However, serum $\mathrm{IgG}$ at weaning at $49 \mathrm{~d}$ was affected by treatment $(\mathrm{P}<0.05)$. As a mean, the piglets of the BCB group had a serum IgG level at $10 \mathrm{~d}(13.8 \pm 1.91 \mathrm{mg} / \mathrm{ml})$ slightly but not significantly lower than that of SCB and SC groups $(14.6 \pm 1.91 \mathrm{mg} / \mathrm{ml}$ and $15.2 \pm 1.68$ $\mathrm{mg} / \mathrm{ml}$ respectively), but greater value of serum $\mathrm{IgG}$ at $49 \mathrm{~d}(16.4 \pm 1.43$ $\mathrm{mg} / \mathrm{ml}$ vs $11.3 \pm 1.47 \mathrm{mg} / \mathrm{ml}$ and $13.3 \pm 2.22 \mathrm{mg} / \mathrm{ml}$ for $\mathrm{SC}$ and $\mathrm{SCB}$ respectively). This value was significantly different from that of SC group, but similar to that of SCB. The serum IgG levels at $49 \mathrm{~d}$ of the SC and SCB groups were similar. The concentrations of porcine $\mathrm{IgG}$ in the piglets serum are shown in table 2.

Table 2: Effect of treatments on the serum concentrations of porcine $\operatorname{IgG}$ at $10 \mathrm{~d}$ and at weaning (49 d)

\begin{tabular}{cccccccc}
\hline Dependent variables & \multicolumn{2}{c}{ SC } & \multicolumn{2}{c}{ SCB } & \multicolumn{2}{c}{ BCB } & \multirow{2}{*}{ Significance test } \\
\cline { 2 - 7 } & Mean & SE & Mean & SE & Mean & SE & \\
\hline Serum IgG at 10 d $(\mathrm{mg} / \mathrm{ml})$ & 15.2 & 1.68 & 14.6 & 1.91 & 13.8 & 1.91 & NS \\
Serum IgG at weaning & $11.3 \mathrm{~b}$ & 1.47 & $13.3 \mathrm{ab}$ & 2.22 & $16.4 \mathrm{a}$ & 1.43 & $*$ \\
(mg/ml) & & & & & & & \\
\hline
\end{tabular}

SC: Sow colostrum; SCB: Sow colostrum butter; BCB: Bovine colostrum butter; SE: Standard error; NS: No significant; *: $\mathrm{P}<0.05$

Proportions of the same row followed by the same letters do not differ significantly at $5 \%$ 


\section{Discussion}

Diarrhea in newborn piglets is an old but still relevant problem in pig production (Larsson, 2016). In this study, diarrhea was the visible symptom in agreement with results obtained later by Agbokounou et al. (2017a) who showed that diarrhea is the visible symptom observed with local piglets fed for the first $48 \mathrm{~h}$ of life with either heated bovine colostrum, or thawed bovine colostrum and thereafter kept under the sow piglets, or colostrum from the mother. This one is a common cause of death in african traditional farms (Youssao et al., 2008; Kouamo et al., 2015; Munzhelele, Oguttu, Fasanmi, \& Fasina, 2017). Larson (2016) reported that diarrhea is estimated to account for $5-24 \%$ of the overall pre-weaning mortality. In this study, piglets that died had suffered from diarrhea. Neonatal diarrhea in pigs are mainly due to viruses (transmissible gastro-enteritis and rotavirus), parasites (coccidia especially) and bacteria (Escherichia coli, strains of Clostridium perfringens and Salmonella spp) (Farzan et al., 2013). Among them coccidia, viruses, Escherichia coli and salmonella are the most common in Africa and particularly in Benin (Mutua et al., 2011; Kpodekon et al., 2013; Bankole et al., 2014). In this study, diarrhea was observed mainly from the $3^{\text {rd }}$ to $4^{\text {th }}$ week in three sows. At this age, piglets are also highly susceptible to enterotoxigenic Escherichia coli (Sugiharto, Poulsen, Canibe, \& Lauridsen, 2015). Diarrhea observed could be caused by Escherichia coli. Donovan (2016) showed that bovine lactoferrin reduces concentrations of Salmonella Spp and Escherichia coli and finally the rate of diarrhea in piglets. This is in agreement with results obtained by Sugiharto et al. (2015) who showed that bovine colostrum was able to reduce the intestinal colonization by enterotoxigenic Escherichia coli. In this study, the risk of diarrhea was not affected by the treatments, but the bovine colostrum treatment tended $(\mathrm{P}=$ $0.0947)$ to reduce this risk. Moreover, the rate of diarrhea in piglets of BCB group was numerically lower than that of the two other Groups (13\% vs 44\% and $57 \%$ for SC and SCB groups respectively). Additionally, compared to $\mathrm{SCB}, \mathrm{SC}$ treatment decreased the risk of diarrhea by 1.7 times whereas BCB decreased it by 9 times. The results of the occurrence of diarrhea from the $3^{\text {rd }}$ to $4^{\text {th }}$ week and the no significant effect of treatment on the risk of diarrhea are in agreement with findings of Agbokounou et al. (2017a) who showed that local piglets feeding for the first $48 \mathrm{~h}$ of life with adequate amount of thawed bovine colostrum did not prevent the onset of diarrhea at the $3^{\text {rd }}$ and $4^{\text {th }}$ week of their life. These results may be associated with the clearance of antimicrobial compounds of bovine colostrum during the three weeks of life. Larsson (2016) reported that no difference in the serum f-globulin concentrations was observed between diarrheic and healthy piglets suggesting that the colostrum intake was adequate. This is in agreement with this study which showed that diarrheic and healthy piglets had the similar average serum 
IgG levels at $10 \mathrm{~d}(13.9 \pm 1.6 \mathrm{mg} / \mathrm{ml}$ vs $14.7 \pm 1.4 \mathrm{mg} / \mathrm{ml}, \mathrm{P}>0.05)$. In sowsuckled piglets, the piglet synthesizes IgG from 7 days of age and this synthesis is positively correlated with IgG absorbed from colostrum (Rooke et al., 2003). Colostrum intake during the first $24 \mathrm{~h}$ of life has a significant role in early postnatal development of both mucosal (i.e. fecal $\operatorname{IgA}$ ) and systemic immunity (i.e. plasma IgG and B cell numbers) of piglets (Ogawa et al., 2016). Furthermore, Ferrari et al. (2014) observed that serum IgG concentration at $10 \mathrm{~d}$ of age was positively correlated $(\mathrm{P}<0.0001)$ with colostrum intake. According to these observations, diarrhea observed between 7 and $14 \mathrm{~d}$ in the piglets of SCB group could not be attributed to low colostrum intake. The composition of the intestinal microflora has been reported to show a large inter-individual variability during the first 1-2 weeks of the piglet's life, followed by a cohabitation effect around 3-4 weeks when the microflora among piglets become alike (Larsson, 2016). These findings could explain the only prevalence of diarrhea in the piglets of SCB group.

No difference in serum $\operatorname{IgG}$ concentration at $10 \mathrm{~d}$ was observed between the three treatment groups (about $14 \mathrm{mg} / \mathrm{ml}$ ). The values are similar to that observed at $10 \mathrm{~d}$ on improved breed sows $(14 \pm 0.2 \mathrm{mg} / \mathrm{ml})$ by Ferrari et al. (2014). These values confirm the adequate colostrum and IgG intake in piglets of the three groups. They also confirm the observations of Agbokounou et al. (2017b) indicating that the local sow breed of Benin is characterized by adequate IgG concentration in colostrum. Based on these values and the emergence of diarrhea, it appears that porcine IgGs have not been able to reduce the prevalence of diarrhea. This study suggests that lyophilized bovine colostrum and shea butter have not promoted uptake of porcine IgG. This result is in contrast with Cabrera et al. (2013) which reported that bovine colostrum, when compared with mature milk, is able to augment the absorption of porcine $\operatorname{IgG}$ by some unknown mechanism. However, bovine colostrum may improve IgG synthesis in the local piglet. Indeed, as previously indicated, piglet synthesizes its own IgG from $7 \mathrm{~d}$ of age. In this study, the concentration of serum IgG at $49 \mathrm{~d}$ was affected by treatment $(\mathrm{P}<0.05)$ with a high value for the BCB group $(16 \pm 1.4 \mathrm{mg} / \mathrm{ml})$ which was significantly different from that of SC group $(11 \pm 1.5 \mathrm{mg} / \mathrm{ml})$, but similar to that of $\mathrm{SCB}(13 \pm 2.2 \mathrm{mg} / \mathrm{ml})$. The no significant difference observed between SC and SCB groups for the serum IgG level at $49 \mathrm{~d}$ and the similarity between $\mathrm{BCB}$ and $\mathrm{SCB}$ groups may be associated to the missing data for this parameter in SCB group. The active immunity is positively correlated with the level of acquisition of the passive immunity (Rooke et al., 2003; Markowska-Daniel, Pomorska-Mól, \& Pejsak, 2010). Indeed, as previously indicated, colostrum intake during the first $24 \mathrm{~h}$ of life has a significant role in early postnatal development of systemic immunity (i.e. plasma IgG and B cell numbers) of piglets. Based on these observations, 
bovine colostrum improved the active immunity at weaning compared to sow colostrum group, this probably through the improvement of B cells synthesis. Additionally, this active immunity improvement could be due to the bovine Ig obtained by the BCB group in addition to the porcine IgG compared with the two other groups. These bovine IgG were not detected in the piglets blood at $10 \mathrm{~d}$ of life. This is in contrast with findings of Stirling et al. (2005) which showed that bovine IgG were detected until 28th day in the blood of young and adult pigs fed bovine colostrum for 7 days. However, animals received only bovine colostrum in the case of these studies. It has been well characterized that piglets can absorb colostrum IgG across the intestine to neonatal bloodstream and a certain level of bovine IgG has been found in the mucosal secretions of the porcine intestinal tract (Guo et al., 2016). The transport of $\operatorname{IgG}$ across the epithelial barrier and into the circulation is achieved in part by the neonatal Fc receptor (FcRn) (Cabrera, Lin, Ashwell, Moeser, \& Odle, 2013). Porcine FcRn was capable of taking up IgG of several species including bovine IgG (Stirling et al., 2005). In the presence of both bovine and porcine $\operatorname{IgG}$, there may be a binding competition between receptors and $\mathrm{IgG}$. In this case, porcine $\mathrm{FcRn}$ would select porcine $\mathrm{IgG}$ preferentially. This in agreement with Drew and Owen (1988) which reported that although the piglet is nonselective in the absorption of macromolecules, it selects porcine IgG preferentially in the presence of other macromolecules and the absorption of porcine IgG and bovine albumin occurred at equal low levels when fed separately. In addition of these results, Viehmann et al. (2015) reported that typically, neonatal piglets preferentially absorb porcine IgG relative to bovine IgG. Likewise, Drew and Owen (1988) have shown that the low absorption of bovine IgG in their study may be due to the inability of porcine IgG receptors to efficiently bind, transport and concentrate bovine IgG. Sugiharto et al. (2015) had also shown that the low capacity of the intestine to absorb bovine Ig and/or gut closure may explain the poor transfer of bovine Ig from the gut to the bloodstream in piglets. In this study, piglets of BCB group were fed with lyophilized bovine colostrum mixed with shea butter. Based on these observations, the absence of bovine $\mathrm{IgG}$ in the blood of piglets may probably be associated with the binding competition between FcRn and IgGs from porcine and bovine colostrum or with the shea butter effect. The bovine IgG could then remain in the intestinal lumen of the animals and would provide local immunity, this in agreement with the observations reported by Sugiharto et al. (2015) indicating that the bovine colostral Ig that are not absorbed by the intestine (remaining in the intestinal lumen) may, however, still provide passive local immunity to piglets by binding to the antigens and protecting the intestinal tissue through immune exclusion. It would provide additional proteins to piglets. The non-significant effect of bovine colostrum on the prevalence of diarrhea may also be due to 
the clearance of some of these bovine Ig at the end of the three weeks of life, date of onset of diarrhea.

The significant drop of body weight and ADG observed between 21 and $28 \mathrm{~d}$ in all groups corresponded to the period of onset of diarrhea in these lots. Moreover, the loss of weight between 7 and $14 \mathrm{~d}$ of life observed only in the animals of the SCB group corresponded to the period of occurrence of the first cases of diarrhea observed only in these piglets. It appears that diarrhea is a common cause of growth performance decline in newborn piglet. This in agreement with the findings of Kongsted (2014) who showed that diarrhea is estimated to reduce ADG by $9-14 \mathrm{~g}$ per day in the pre-weaning piglets. These growth parameters were not influenced by piglet supplementation with lyophilized bovine colostrum and / or with shea butter because no significant difference $(\mathrm{P}>0.05)$ was observed between the three groups for the body weight and ADG. These results are similar to those of Viehmann et al. (2015) who observed during $10 \mathrm{~d}$ of trial no significant effect on mortality, body weight, and ADG of pre-weaned piglets supplemented over 3 days with bovine colostrum. However, piglets supplementation with lyophilized bovine colostrum improved their RADG because a significant difference for this parameter was observed between the three treatment groups with a better gain for the BCB group (31 g/d.kg vs $25 \mathrm{~g} / \mathrm{d} . \mathrm{kg}$ for the SC and SCB groups) and RADG was not affected by the treatment*time interaction $(\mathrm{P}>0.05)$. The number of diarrhea cases observed in the SC and $\mathrm{SCB}$ groups was numerically greater than that observed in the BCB group (4 piglets for each of the two groups vs 1 for the BCB group). The ADG dropped due to these diarrheas previously indicated would be less in the BCB group and could explain this observed difference between the treatment groups for the RADG. Piglets supplementation under the mother with lyophilized bovine colostrum increased their RADG probably through reducing the diarrhea effects on the ADG. It has improved numerically these ADGs compared to piglets fed only with colostrum from the sow and those fed with colostrum from the sow and shea butter (41g vs 35 and $36 \mathrm{~g}$ for the first and second groups respectively). Finally, a higher RADG reflect also an ability of animal tissues to maintain growth, in the course of the time. It must be noted that the ADG obtained with lyophilized bovine colostrum is lower than that reported at $49 \mathrm{~d}$ of age by Agbokounou et al. (2017a) with local piglets fed for $48 \mathrm{~h}$ with thawed bovine colostrum and thereafter kept under the sow $(52 \mathrm{~g} / \mathrm{d})$. Shea butter supplementation as energy source had no effect on the growth of the animals. Thus, any confounding effect between shea butter and lyophilized colostrum could be excluded.

Diarrhea causes huge economic losses per sow and year (Larsson, 2016). The present study has shown that the supplementation of suckling local piglets breed with lyophilized bovine colostrum tends to reduce the 
prevalence of diarrhea and therefore can reduce these economic losses in small farmers with vulnerable resources. This supplementation has also improved the immune status of piglets at weaning preparing them to resist better than other piglets to the post-weaning pathologies, which will limit the economic losses and the use of antibiotics. Ultimately, this study offers a strategy to increase farmers profits and improve the quality of life of their animals and their own quality of life.

\section{Conclusion}

The supplementation of suckling local piglets breed with lyophilized bovine colostrum could not significantly reduce the risk of diarrhea but increased the RADG probably thanks to a reduction of the diarrhea effects on the ADG. The present study showed that bovine IgGs were not detected in the piglets blood suggesting a binding competition between IgGs from porcine and bovine colostrum at the level of FcRn receptors, with a preference of these receptors for porcine IgG. However, although the lack of detectable transfer of these IgG into the blood, they could provide local immunity. Bovine colostrum improved active immunity in local piglets breed through increase of the serum concentration of porcine $\mathrm{IgG}$ at weaning.

\section{Acknowledgments}

This work was carried out by means of the collaboration between the University of Abomey-Calavi in Benin and the Faculty of Medicine Veterinary, University of Liège, in Belgium. It was supported by the Faculty of Medicine Veterinary of the University of Liège (Financial support) and the Government of Benin (national scholarship). We would like to express our gratitude to the authorities of both institutions.

\section{Conflict of Interest}

The authors declare no conflicts of interest.

\section{References:}

1. Agbokounou, A. M., Ahounou, G. S., Youssao, A. K. I., Mensah, G. A., Koutinhouin, B., \& Hornick, J-L. (2017a). Effect of cow colostrum on the performance and survival rate of local newborn piglets in Benin Republic. Tropical Animal Health and Production, 49, 287-294. doi:10.1007/s11250-016-1191-6

2. Agbokounou, A. M., Ahounou, G. S., Bengaly, Z., Youssao, A. K. I., Mensah, G. A., Koutinhouin, B., \& Hornick, J-L. (2017b). Colostrum immune quality of local sow breed in Benin: Growth, survival and acquisition of passive immunity in new-born piglet. African Journal of Biotechnology, 16, 842-851. doi:10.5897/AJB2017.15876 
3. Bankole, H. S., Dougnon, V. T., Johnson, R. C., Dougnon, T. J., Yehouenou, B., Kougblenou, S., Agonsa, M., Legonou, M., Dadie, T., \& Baba-Moussa, L. (2014). Assessment of the Contamination of Some Foodstuffs by Escherichia coli 0157 in Benin, West Africa. International Journal of Microbiology, 2014, 1-8. http://dx.doi.org/10.1155/2014/417848

4. Boudry, C. (2009). 'Effets biologiques et immunitaires du colostrum bovin sur le porcelet au sevrage.'Thèse de doctorat, Faculté universitaire des Sciences agronomiques de Gembloux, Belgique.

5. Cabrera, R., Lin, X., Ashwell, M., Moeser, A., \& Odle, J. (2013). Early postnatal kinetics of colostral immunoglobulin $\mathrm{G}$ absorption in fed and fasted piglets and developmental expression of the intestinal immunoglobulin G receptor. Journal of Animal Science, 91, 211-218. doi:10.2527/jas2011-4426

6. Donovan, S. M. (2016). The Role of Lactoferrin in Gastrointestinal and Immune Development and Function: A Preclinical Perspective. Journal of Pediatrics, 173S, S16-28. doi: 10.1016/j.jpeds.2016.02.072

7. Drew, D. M., \& Owen, D. B. (1988). The provision of passive immunity to colostrum-deprived piglets by bovine or porcine serum immunoglobulins. Canadian Journal of Animal Science, 68, 12771284. https://doi.org/10.4141/cjas88-143

8. Farzan, A., Kircanski, J., DeLay, J., Soltes, G., Songer, J. G., Friendship, R., \& Prescott, J. F. (2013). An investigation into the association between cpb2-encoding Clostridium perfringens type A and diarrhea in neonatal piglets. The Canadian Journal of Veterinary Research, 77, 45-53. https://www.canadianveterinarians.net/scienceknowledge/cjvr

9. Ferrari, C. V., Sbardella, P. E., Bernardi, M. L., Coutinho, M. L., Vaz Jr, I. S., Wentz, I., \& Bortolozzo, F. P. (2014). Effect of birth weight and colostrum intake on mortality and performance of piglets after cross-fostering in sows of different parities. Preventive Veterinary Medicine 114, 259-266. http://dx.doi.org/10.1016/j.prevetmed.2014.02.013

10. Guo, J., Li, F., He, Q., Jin, H., Liu, M., Li, S., Hu, S., Xiao, Y., Bi, D., \& Li, Z. (2016). Neonatal Fc Receptor-Mediated IgG Transport Across Porcine Intestinal Epithelial Cells: Potentially Provide the Mucosal Protection. DNA AND CELL BIOLOGY, 35, 301-309. doi:10.1089/dna.2015.3165

11. Kouamo, J., Tassemo Tankou, W. F., Zoli, A. P., Bah, G. S., \& Ngo Ongla, A. C. (2015). Assessment of reproductive and growth performances of pig breeds in the peri-urban area of Douala (Equatorial Zone). Open Veterinary Journal 5, 64-70. 
https://www.ncbi.nlm.nih.gov/pmc/articles/PMC4629558/

12. Kongsted, H., Stege, H., Toft, N., \& Nielsen, J. P. (2014). The effect of New Neonatal Porcine Diarrhoea Syndrome (NNPDS) on average daily gain and mortality in 4 Danish pig herds. BMC Veterinary Research, 10, p.90. doi:10.1186/1746-6148-10-90

13. Kpodekon, M. T., Goussanou, J. S. E., Attakpa, E. Y., Boko, C. K., Ahounou, S. G., Salifou, C. F., Tougan, U. P., \& Youssao, A. K. I. (2013). Evaluation of macroscopic and microbiological hazards of indigenous pork consumption in south of Benin. International Journal of Current Microbiology and Applied Sciences 2, 98-109. https://www.researchgate.net/publication/311452669

14. Larsson, J. (2016). ‘Neonatal Porcine Diarrhoea. Aspects on Aetiology and Pathology.' PhD thesis, Swedish University of Agricultural Sciences.

15. Markowska-Daniel, I., Pomorska-Mól, M., \& Pejsak, Z. (2010). Dynamic changes of immunoglobulin concentrations in pig colostrum and serum around parturition. Polish Journal of Veterinary Sciences, 13, 21-27. https://www.ncbi.nlm.nih.gov/pubmed/21077427

16. Munzhelele, P., Oguttu, J., Fasanmi, O. G., \& Fasina, F. O. (2017). Production constraints of smallholder pig farms in agro-ecological zones of Mpumalanga, South Africa. Tropical Animal Health and Production, 49, 63-69. doi:10.1007/s11250-016-1158-7

17. Mutua, F. K., Dewey, C. E., Arimi, S. M., Schelling, E., Ogara, W. O., \& Levy, M. (2011). Reproductive performance of sows in rural communities of Busia and Kakamega Districts, Western Kenya. African Journal of Agricultural Research, 6, 64856491.http://www.aasv.org/shap.html

18. Nonfon, W. R. (2005). La filière de production du porc local au Bénin : l'amélioration de sa productivité par l'alimentation. Thèse de Doctorat en Sciences agronomiques et Ingénierie biologique, Faculté Universitaire des Sciences Agronomiques de Gembloux, Belgique, $236 \mathrm{p}$.

19. Ogawa, S., Tsukahara, T., Imaoka, T., Nakanishi, N., Ushida, K., \& Inoue, R. (2016). The effect of colostrum ingestion during the first 24 hours of life on early postnatal development of piglet immune systems. Animal Science Journal, 87, 1511-1515. doi:10.1111/asj.12573

20. Osseni, A. A., Sinsin, B., \& Toko, I. I. (2014). Analyse des contraintes de viabilité de la végétation urbaine : cas des arbres d'alignement dans la ville de Porto-Novo au Bénin. European Scientific Journal 10: 115. 
21. Quesnel, H., Farmer, C., \& Devillers, N. (2012). Colostrum intake: Influence on piglet performance and factors of variation. Livestock Science, 146, 105-114. https://doi.org/10.1016/j.livsci.2012.03.010

22. Rooke, A. J., Carranca, C., Bland, M. I., Sinclair, G. A., Ewen, M., Bland, C. V., \& Edwards, S. A. (2003). Relationships between passive absorption of immunoglobulin $\mathrm{G}$ by the piglet and plasma concentrations of immunoglobulin $\mathrm{G}$ at weaning. Livestock Production Science, 81, 223-234. https://doi.org/10.1016/S03016226(02)00260-9

23. Stirling, C. M. A., Charleston, B., Takamatsu, H., Claypool, S., Lencer, W., Blumberg, R. S., \& Wileman, T. E. (2005). Characterization of the porcine neonatal $\mathrm{Fc}$ receptor-potential use for trans-epithelial protein delivery. Immunology 114, 542-553. doi: 10.1111/j.13652567.2004.02121.x

24. Sugiharto, S., Poulsen, A-S. R., Canibe, N., \& Lauridsen, C. (2015). Effect of bovine colostrum feeding in comparison with milk replacer and natural feeding on the immune responses and colonisation of enterotoxigenic Escherichia coli in the intestinal tissue of piglets. British Journal of Nutrition, 113, 923-934. doi:10.1017/S0007114514003201

25. Viehmann, M., Unterweger, C., Ganter, M., Metzler-Zebeli, B. U., Ritzmann, M., Hennig-Pauka, I. (2015). Effects of bovine colostrum on performance, survival, and immunoglobulin status of suckling piglets during the first days of life. Czech Journal of Animal Science, 60, 351-358. doi:10.17221/8404-CJAS

26. Youssao, A. K. I., Koutinhouin, G. B., Kpodekon, T. M., Bonou, A. G., Adjakpa, A., Dotcho, C. D. G., \& Atodjinou, F. T. R. (2008). Production porcine et ressources génétiques locales en zone périurbaine de Cotonou et d'Abomey-Calavi au Bénin. Revue d'Elevage et de Médecine Vétérinaire des Pays Tropicaux 61, 235-243. doi:http://dx.doi.org/10.19182/remvt.9995 